\title{
STUDIES ON NEOPLASMS WITH THE AID OF RADIOACTIVE PHOSPHORUS. I. THE TOTAL PHOSPHORUS METABO- LISM OF NORMAL AND LEUKEMIC MICE ${ }^{1}$
}

\author{
By J. H. LAWRENCE, L, W. TUTTLE, K. G. SCOTT, ANd C. L. CONNOR \\ (From the Crocker Radiation Laboratory and the Departments of Medicine and Pathology, \\ University of California, Berkeley)
}

(Received for publication October 24, 1939)

In a previous study (1) using " tagged" phosphorus, it was found that lymphomatous mice handle a single dose of sodium phosphate in a manner different from normal animals. Lymphomatous tissue absorbed or exchanged phosphorus in greater degree than normal lymph nodes, and this seemed to occur at the expense of the uptake in bone in these animals.

Before investigating this question further in leukemic animals, it seemed important first to determine the content of total phosphorus in various lymphomatous, leukemic and normal tissues. One might suspect that the greater exchange of phosphorus in lymphomatous tissue was related to a greater total phosphorus content. The analyses were carried out using the methods of Pregl (2) for total phosphorus. The animals were young adults of the Strong A strain (3), with males and females equally distributed between the normal and leukemic animals. Most of them were given the disease (4) by the intravenous injection of leukemic cells but a few were inoculated subcutaneously, the latter method resulting in the appearance of a local lymphoma followed later by the generalized disease. In all instances the animals were killed by breaking the neck and the tissues were immediately weighed and prepared for phosphorus analysis. In all cases, gross evidence of generalized leukemia was found in the leukemic group. Examination of Table I reveals that there is no significant difference in the total phosphorus contents of leukemic spleens, leukemic lymph nodes, and leukemic bones ${ }^{2}$ when compared with the respective normal tissues, in spite of the fact that, in leukemic animals, all of these tissues are infiltrated with leukemic cells. Likewise, the values for skeletal muscle are the same

\footnotetext{
1 This work was made possible through a grant from the Josiah Macy, Jr. Foundation.

2 The whole femurs were used in these analyses.
}

in the two groups of animals. This latter finding was to be expected, since there usually is no leukemic infiltration of skeletal muscle in this disease. Finally, tumor or lymphomatous tissue has a significantly lower total phosphorus content than its analogue-normal lymph node. Despite the fact that the phosphorus content of leukemic liver may be significantly lower than that of normal liver, these results show that any difference in the exchange of a single dose of phosphorus observed in lymphomatous or leukemic animals cannot be explained on the basis of differences in the total phosphorus values.

We wish to report here further studies on the comparative uptake and turnover of "labelled" phosphorus in a large group of normal and leukemic animals.

\section{Procedure}

In the experiments to be reported here, adult animals of the A strain were used, and the leukemia was transmitted to them by the intravenous inoculation of a suspension of lymphomatous cells. After the onset of the leukemia, as evidenced by enlarged spleens and lymph nodes, leukemic and control animals were given intraperitoneally a single tracer dose of radioactive phosphorus in the form of an isotonic solution of neutral sodium phosphate. At various periods thereafter leukemic and control animals were sacrificed and their tissues were freshly weighed, dried and ashed at $450^{\circ} \mathrm{C}$. Afterwards the ashes were measured for beta-ray activity, using a Lauritsen type electroscope or an electrometer. The radioactive phosphorus $\left(\mathrm{P}^{2}\right)$ which has a half life of 14.3 days was prepared in the Berkeley cyclotron (5) by the bombardment of red phosphorus $\left(P^{31}\right)$ with high speed deuterons. Thereafter it was converted to a neutral solution of sodium phosphate.

Forty female mice, varying in ages from 5 to 8 months were used in this study. The animals were divided into eight groups of 5 mice each, and 20 of them were given intravenously in 0.1 cc. $9,300,000$ lymphomatous cells. Groups of 5 animals were placed in individual cages, having raised wire floors so that coprophagy was avoided. All animals were given free access to water and they were fed on dog chow. The weighed daily food in- 
TABLE I

Total phosphorus in tissues of normal and leukemic mice*

\begin{tabular}{|c|c|c|c|c|c|c|c|c|}
\hline Tissue & $\begin{array}{l}\text { Normal } \\
\text { or } \\
\text { leukemic }\end{array}$ & $\begin{array}{l}\text { Number } \\
\text { of } \\
\text { animals }\end{array}$ & $\begin{array}{l}\text { Mean } \\
\mathrm{mg} P / \mathrm{g}\end{array}$ & ex & - $M$ & $M_{N}-M_{L}$ & $\sigma M_{N}-M_{L}$ & \\
\hline Liver & $\mathbf{N}$ & 46 & 3.86 & 0.35 & 0.051 & 0.27 & 0.074 & $\begin{array}{l}\text { Difference is of possible sig- } \\
\text { nificance }\end{array}$ \\
\hline Liver & L & 39 & 3.59 & 0.33 & 0.053 & & & \\
\hline $\begin{array}{l}\text { Spleen } \\
\text { Spleen }\end{array}$ & $\begin{array}{l}\mathrm{N} \\
\mathrm{L}\end{array}$ & $\begin{array}{l}22 \\
39\end{array}$ & $\begin{array}{l}4.58 \\
4.77\end{array}$ & $\begin{array}{l}0.52 \\
0.27\end{array}$ & $\begin{array}{l}0.11 \\
0.043\end{array}$ & 0.19 & 0.12 & Difference is not significant \\
\hline $\begin{array}{l}\text { Lymph node } \\
\text { Lymph node }\end{array}$ & $\begin{array}{l}\mathbf{N} \\
\mathbf{L}\end{array}$ & $\begin{array}{l}40 \\
27\end{array}$ & $\begin{array}{l}5.67 \\
5.81\end{array}$ & $\begin{array}{l}0.74 \\
1.24\end{array}$ & $\begin{array}{l}0.117 \\
0.238\end{array}$ & 0.14 & 0.265 & Difference is not significant \\
\hline $\begin{array}{l}\text { Bone } \\
\text { Bone }\end{array}$ & $\begin{array}{l}\mathbf{N} \\
\mathbf{L}\end{array}$ & $\begin{array}{l}40 \\
28\end{array}$ & $\begin{array}{l}75.6 \\
73.2\end{array}$ & $\begin{array}{l}9.9 \\
9.9\end{array}$ & $\begin{array}{l}1.57 \\
1.87\end{array}$ & 2.4 & 2.45 & Difference is not significant \\
\hline $\begin{array}{l}\text { Muscle } \\
\text { Muscle }\end{array}$ & $\begin{array}{l}\mathbf{N} \\
\mathrm{L}\end{array}$ & $\begin{array}{l}37 \\
53\end{array}$ & $\begin{array}{l}3.02 \\
3.00\end{array}$ & $\begin{array}{l}0.47 \\
0.33\end{array}$ & $\begin{array}{l}0.064 \\
0.054\end{array}$ & 0.02 & 0.084 & Difference is not significant \\
\hline $\begin{array}{c}\text { Tumor (lym- } \\
\text { phoma) }\end{array}$ & & 29 & 4.14 & 0.34 & 0.064 & & & \\
\hline
\end{tabular}

* $\sigma_{X}=$ Standard deviation of individual values $=\sqrt{\Sigma x^{2} / n}$ where $x$ equals the difference of the individual values from the mean.

$M_{N}-M_{L}=$ Difference of mean values for normal and leukemic tissues.

$\sigma_{M}=$ Standard error of the mean $=\sigma_{X} / \sqrt{n}$.

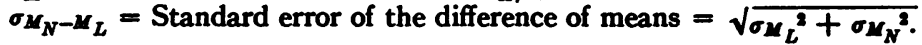

Criterion of significance: If the difference of the means exceeds three times the standard error of the difference of the means, the difference is considered to be of possible significance.

take of each group of leukemic animals determined the amount of food given to its control group on the following day. This tended to make uniform the total daily phosphorus intake of the two groups. Each group of leukemic animals exhibited enlarged spleens when the phosphorus was administered, and all animals (leukemic and control) were sacrificed 16 days after inoculation with leukemia. The radio-phosphorus was administered intraperitoneally in the form of $0.5 \mathrm{cc}$. of a solution containing $7 \mathrm{mgm}$. sodium phosphate at a $\mathrm{pH}$ of 7 , having a $\mathrm{P}^{\mathrm{s}}$ activity of 9.5 microcuries when the first group was injected. Five normal and 5 leukemic animals were each given this injection $100,52,26$ and 17 hours before all the animals were sacrificed. At autopsy, there was gross evidence of leukemia in the 20 leukemic animals. Microscopic examination of small portions of spleen, liver, lymph node, and bone marrow in each animal of this group revealed leukemic infiltration, whereas in no case was there infiltration of skeletal muscle. Certain individual tissues and the remaining carcasses of each group of 5 leukemic and 5 control mice were lumped, ${ }^{8}$ weighed,

${ }^{8}$ Although it is desirable to analyze the tissues of each mouse individually, in these experiments the tissues of 5 animals were lumped since the total weight of the lymph nodes of single normal animals and their uptake of labelled phosphorus are so low that accurate activity analyses are difficult. Three of us (J. H. L., L. W. T., and $K$. G. S.) have confirmed the findings given here in separate experiments not here reported. ashed and then assayed for beta ray activity. In this manner, the per cent retention of the dose given, in terms of one gram of whole animal, liver, spleen, lymph node, muscle and bone was determined. The data thus obtained are given in Table II and plotted in Figure 1.

Figure 1 shows that per gram of whole body, leukemic animals take up slightly more phosphorus than normal, but exchange or lose it at about the same rate as normal animals over the period of 100 hours. Skeletal muscle of leukemic animals took up less at first, but later the uptake was approximately normal. It should be noted that there was no leukemic infiltration of the muscle in the leukemic animals. A striking difference, however, is noted in the lymph glands where the uptake by leukemic lymph nodes is approximately three times normal, which is also true of leukemic spleen where the loss of labelled phosphorus is also relatively greater over the period of 100 hours. The curves for bone, which include bone and bone marrow, show that leukemic bone has slightly the greater activity, but the rate of exchange is about the same as normal. The curves for liver are nearly the same for the normal and leukemic animals. 
TABLE II

Labelled phosphorus in tissues of normal and leukemic mice* 17 HOURS AFTER P" ADMinistration (NORMAL vs. LEUKEMIC MICE)

\begin{tabular}{|c|c|c|c|c|c|}
\hline Tissue & $\begin{array}{c}\text { Normal } \\
\text { or } \\
\text { leu- } \\
\text { kemic }\end{array}$ & $\begin{array}{c}\text { Wet } \\
\text { weight }\end{array}$ & $\begin{array}{c}\text { Activity } \\
\text { in } \\
\text { micro- } \\
\text { curies } \\
\text { per } \\
\text { gram }\end{array}$ & $\begin{array}{l}\text { Reten- } \\
\text { tion per } \\
\text { gram } \\
\text { in } \\
\text { per cent } \\
\text { of dose }\end{array}$ & $\begin{array}{c}\text { Per } \\
\text { cent } \\
\text { of } \\
\text { normal }\end{array}$ \\
\hline $\begin{array}{l}\text { Lymph node } \\
\text { Lymph node }\end{array}$ & $\begin{array}{l}\mathbf{N} \\
\mathrm{L}\end{array}$ & $\begin{array}{l}0.126 \\
0.327\end{array}$ & $\begin{array}{l}0.103 \\
0.22\end{array}$ & $\begin{array}{l}\text { per cent } \\
2.2 \\
4.7\end{array}$ & $\begin{array}{c}\text { per cent } \\
214\end{array}$ \\
\hline $\begin{array}{l}\text { Spleen } \\
\text { Spleen }\end{array}$ & $\begin{array}{l}\mathbf{N} \\
\mathbf{L}\end{array}$ & $\begin{array}{l}0.640 \\
3.705\end{array}$ & $\begin{array}{l}0.127 \\
0.385\end{array}$ & $\begin{array}{l}2.7 \\
8.2\end{array}$ & 302 \\
\hline $\begin{array}{l}\text { Liver } \\
\text { Liver }\end{array}$ & $\begin{array}{l}\mathrm{N} \\
\mathrm{L}\end{array}$ & $\begin{array}{l}6.490 \\
9.990\end{array}$ & $\begin{array}{l}0.184 \\
0.189\end{array}$ & $\begin{array}{l}3.84 \\
4.0\end{array}$ & 104 \\
\hline $\begin{array}{l}\text { Muscle } \\
\text { Muscle }\end{array}$ & $\begin{array}{l}\mathbf{N} \\
\mathrm{L}\end{array}$ & $\begin{array}{l}4.684 \\
4.210\end{array}$ & $\begin{array}{l}0.085 \\
0.057\end{array}$ & $\begin{array}{l}1.8 \\
1.22\end{array}$ & 68 \\
\hline $\begin{array}{l}\text { Bone } \\
\text { Bone }\end{array}$ & $\begin{array}{l}\mathbf{N} \\
\mathrm{L}\end{array}$ & $\begin{array}{l}0.682 \\
0.705\end{array}$ & $\begin{array}{l}0.167 \\
0.185\end{array}$ & $\begin{array}{l}3.56 \\
3.96\end{array}$ & 111 \\
\hline $\begin{array}{l}\text { Balance } \\
\text { Balance }\end{array}$ & $\begin{array}{l}\mathbf{N} \\
\mathbf{L}\end{array}$ & $\begin{array}{l}109 \\
104.0\end{array}$ & $\begin{array}{l}0.077 \\
0.081\end{array}$ & $\begin{array}{l}1.64 \\
1.72\end{array}$ & 105 \\
\hline $\begin{array}{l}\text { Total animal } \\
\text { Total animal }\end{array}$ & $\underset{\mathrm{L}}{\mathbf{N}}$ & $\begin{array}{l}121.6 \\
122.9\end{array}$ & $\begin{array}{l}0.084 \\
0.099\end{array}$ & $\begin{array}{l}1.79 \\
2.1\end{array}$ & 117 \\
\hline
\end{tabular}

* All activities corrected to January 18, 1939.

Average retention per normal animal of tagged phosphorus administered $\mathbf{4 3 . 5}$ per cent.

Average retention per leukemic animal of tagged phosphorus administered $\mathbf{5 2}$ per cent.

26 HOURS AFTER Pæ ADMINISTRATION (NORMAL MICE VS. LEUKEMIC MICE)

\begin{tabular}{|c|c|c|c|c|c|}
\hline Tissue & $\begin{array}{c}\text { Normal } \\
\text { or } \\
\text { leu- } \\
\text { kemic }\end{array}$ & $\begin{array}{c}\text { Wet } \\
\text { weight }\end{array}$ & $\begin{array}{c}\text { Activity } \\
\text { in micro- } \\
\text { curies } \\
\text { per gram } \\
\text { wet } \\
\text { weight }\end{array}$ & $\begin{array}{l}\text { Reten- } \\
\text { tion per } \\
\text { gram } \\
\text { in } \\
\text { per cent } \\
\text { of dose }\end{array}$ & $\begin{array}{c}\text { Per } \\
\text { cent } \\
\text { of } \\
\text { normal }\end{array}$ \\
\hline $\begin{array}{l}\text { Lymph node } \\
\text { Lymph node }\end{array}$ & $\begin{array}{l}\mathbf{N} \\
\mathbf{L}\end{array}$ & $\begin{array}{l}0.225 \\
0.282\end{array}$ & $\begin{array}{l}0.105 \\
0.270\end{array}$ & $\begin{array}{c}\text { per cent } \\
2.23 \\
5.77\end{array}$ & $\begin{array}{c}\text { per cent } \\
259\end{array}$ \\
\hline $\begin{array}{l}\text { Spleen } \\
\text { Spleen }\end{array}$ & $\begin{array}{l}\mathbf{N} \\
\mathbf{L}\end{array}$ & $\begin{array}{l}0.723 \\
3.550\end{array}$ & $\begin{array}{l}0.144 \\
0.280\end{array}$ & $\begin{array}{l}3.06 \\
6.0\end{array}$ & 196 \\
\hline $\begin{array}{l}\text { Liver } \\
\text { Liver }\end{array}$ & $\begin{array}{l}\mathbf{N} \\
\mathbf{L}\end{array}$ & $\begin{array}{r}6.802 \\
10.860\end{array}$ & $\begin{array}{l}0.178 \\
0.187\end{array}$ & $\begin{array}{l}3.78 \\
4.0\end{array}$ & 106 \\
\hline $\begin{array}{l}\text { Muscle } \\
\text { Muscle }\end{array}$ & $\underset{\mathrm{L}}{\mathbf{N}}$ & $\begin{array}{l}2.745 \\
3.865\end{array}$ & $\begin{array}{l}0.120 \\
0.076\end{array}$ & $\begin{array}{l}2.56 \\
1.6\end{array}$ & 63 \\
\hline $\begin{array}{l}\text { Bone } \\
\text { Bone }\end{array}$ & $\begin{array}{l}\mathbf{N} \\
\mathbf{L}\end{array}$ & $\begin{array}{l}0.772 \\
0.670\end{array}$ & $\begin{array}{l}0.156 \\
0.199\end{array}$ & $\begin{array}{l}3.3 \\
4.2\end{array}$ & 127 \\
\hline $\begin{array}{l}\text { Balance } \\
\text { Balance }\end{array}$ & $\begin{array}{l}\mathbf{N} \\
\mathbf{L}\end{array}$ & 114 & $\begin{array}{l}0.070 \\
0.885\end{array}$ & $\begin{array}{l}1.49 \\
1.87\end{array}$ & 126 \\
\hline $\begin{array}{l}\text { Total animal } \\
\text { Total animal }\end{array}$ & $\begin{array}{l}\mathbf{N} \\
\mathbf{L}\end{array}$ & $\begin{array}{l}125.2 \\
118.7\end{array}$ & $\begin{array}{l}0.078 \\
0.95\end{array}$ & $\begin{array}{l}1.66 \\
2.01\end{array}$ & 121 \\
\hline
\end{tabular}

Average retention per normal animal of tagged phosphorus administered $\mathbf{4 2}$ per cent.

Average retention per leukemic animal of tagged phosphorus administered $\mathbf{4 8 . 4}$ per cent.
TABLE II-Continued

52 HOURS AFTER PE ADMINISTRATION (NORMAL VS. LEUKEMIC MICE)

\begin{tabular}{|c|c|c|c|c|c|}
\hline Tissue & $\begin{array}{c}\text { Normal } \\
\text { or } \\
\text { leu- } \\
\text { kemic }\end{array}$ & $\begin{array}{c}\text { Wet } \\
\text { weight }\end{array}$ & $\begin{array}{c}\text { Activity } \\
\text { in micro- } \\
\text { curies } \\
\text { per gram } \\
\text { wett } \\
\text { weight }\end{array}$ & $\begin{array}{c}\text { Reten- } \\
\text { tion per } \\
\text { gram } \\
\text { in } \\
\text { per cent } \\
\text { of dose }\end{array}$ & $\begin{array}{c}\text { Per } \\
\text { cent } \\
\text { of } \\
\text { normal }\end{array}$ \\
\hline $\begin{array}{l}\text { Lymph node } \\
\text { Lymph node }\end{array}$ & $\begin{array}{l}\mathbf{N} \\
\mathbf{L}\end{array}$ & $\begin{array}{l}0.245 \\
0.642\end{array}$ & $\begin{array}{l}0.102 \\
0.230\end{array}$ & $\begin{array}{c}\text { per cent } \\
2.18 \\
4.88\end{array}$ & $\begin{array}{c}\text { per cent } \\
223\end{array}$ \\
\hline $\begin{array}{l}\text { Spleen } \\
\text { Spleen }\end{array}$ & $\begin{array}{l}\mathbf{N} \\
\mathbf{L}\end{array}$ & $\begin{array}{l}0.920 \\
4.600\end{array}$ & $\begin{array}{l}0.216 \\
0.217\end{array}$ & $\begin{array}{l}4.6 \\
4.62\end{array}$ & 101 \\
\hline $\begin{array}{l}\text { Liver } \\
\text { Liver }\end{array}$ & $\begin{array}{l}\mathrm{N} \\
\mathrm{L}\end{array}$ & $\begin{array}{r}5.900 \\
10.358\end{array}$ & $\begin{array}{l}0.159 \\
0.171\end{array}$ & $\begin{array}{l}3.37 \\
3.68\end{array}$ & 109 \\
\hline $\begin{array}{l}\text { Muscle } \\
\text { Muscle }\end{array}$ & $\begin{array}{l}\mathbf{N} \\
\mathbf{L}\end{array}$ & $\begin{array}{l}3.730 \\
2.550\end{array}$ & $\begin{array}{l}0.076 \\
0.086\end{array}$ & $\begin{array}{l}1.62 \\
1.83\end{array}$ & 113 \\
\hline $\begin{array}{l}\text { Bone } \\
\text { Bone }\end{array}$ & $\begin{array}{l}\mathbf{N} \\
\mathbf{L}\end{array}$ & $\begin{array}{l}0.745 \\
0.465\end{array}$ & $\begin{array}{l}0.211 \\
0.232\end{array}$ & $\begin{array}{l}4.5 \\
4.95\end{array}$ & 110 \\
\hline $\begin{array}{l}\text { Balance } \\
\text { Balance }\end{array}$ & $\stackrel{\mathbf{N}}{\mathrm{L}}$ & $\begin{array}{l}90.96 \\
78.000\end{array}$ & $\begin{array}{l}0.082 \\
0.089\end{array}$ & $\begin{array}{l}1.74 \\
1.9\end{array}$ & 109 \\
\hline $\begin{array}{l}\text { Total animal } \\
\text { Total animal }\end{array}$ & $\stackrel{N}{\mathrm{~N}}$ & $\begin{array}{r}104.5 \\
96.6\end{array}$ & $\begin{array}{l}0.087 \\
0.105\end{array}$ & $\begin{array}{l}1.85 \\
2.24\end{array}$ & 121 \\
\hline
\end{tabular}

Average retention per normal animal of the tagged phosphorus administered 38.4 per cent.

Average retention per leukemic animal of the tagged phosphorus administered $\mathbf{5 4 . 3}$ per cent.

100 HOURS AFTER P: ADMINISTRATION (NORMAL vS. LEUKEMIC MICE)

\begin{tabular}{|c|c|c|c|c|c|}
\hline Tissue & $\begin{array}{c}\text { Normal } \\
\text { or } \\
\text { leu- } \\
\text { kemic }\end{array}$ & $\begin{array}{c}\text { Wet } \\
\text { weight }\end{array}$ & $\begin{array}{c}\text { Activity } \\
\text { in micro- } \\
\text { curies } \\
\text { per gram } \\
\text { wet } \\
\text { weight }\end{array}$ & $\begin{array}{c}\text { Reten- } \\
\text { tion per } \\
\text { gram } \\
\text { in } \\
\text { per cent } \\
\text { of dose }\end{array}$ & $\begin{array}{c}\text { Per } \\
\text { cent } \\
\text { of } \\
\text { normal }\end{array}$ \\
\hline $\begin{array}{l}\text { Lymph node } \\
\text { Lymph node }\end{array}$ & $\begin{array}{l}\mathbf{N} \\
\mathbf{L}\end{array}$ & $\begin{array}{l}0.220 \\
0.413\end{array}$ & $\begin{array}{l}0.109 \\
0.200\end{array}$ & $\begin{array}{c}\text { per cent } \\
2.32 \\
4.28\end{array}$ & $\begin{array}{c}\text { per cent } \\
185\end{array}$ \\
\hline $\begin{array}{l}\text { Spleen } \\
\text { Spleen }\end{array}$ & $\underset{\mathbf{L}}{\mathbf{N}}$ & $\begin{array}{l}0.720 \\
2.777\end{array}$ & $\begin{array}{l}0.110 \\
0.179\end{array}$ & $\begin{array}{l}2.34 \\
3.82\end{array}$ & 168 \\
\hline $\begin{array}{l}\text { Liver } \\
\text { Liver }\end{array}$ & $\begin{array}{l}\mathbf{N} \\
\mathbf{L}\end{array}$ & $\begin{array}{l}5.042 \\
9.365\end{array}$ & $\begin{array}{l}0.101 \\
0.112\end{array}$ & $\begin{array}{l}2.14 \\
2.39\end{array}$ & 112 \\
\hline $\begin{array}{l}\text { Muscle } \\
\text { Muscle }\end{array}$ & $\begin{array}{l}\mathrm{N} \\
\mathrm{L}\end{array}$ & $\begin{array}{l}4.054 \\
3.642\end{array}$ & $\begin{array}{l}0.063 \\
0.056\end{array}$ & $\begin{array}{l}1.34 \\
1.2\end{array}$ & 90 \\
\hline $\begin{array}{l}\text { Bone } \\
\text { Bone }\end{array}$ & $\begin{array}{l}\mathbf{N} \\
\mathbf{L}\end{array}$ & $\begin{array}{l}0.521 \\
0.486\end{array}$ & $\begin{array}{l}0.206 \\
0.247\end{array}$ & $\begin{array}{l}4.38 \\
5.25\end{array}$ & 120 \\
\hline $\begin{array}{l}\text { Balance } \\
\text { Balance }\end{array}$ & $\begin{array}{l}\mathbf{N} \\
\mathbf{L}\end{array}$ & $\begin{array}{c}101.000 \\
95.92\end{array}$ & $\begin{array}{l}0.055 \\
0.066\end{array}$ & $\begin{array}{l}1.18 \\
1.4\end{array}$ & 118 \\
\hline $\begin{array}{l}\text { Total animal } \\
\text { Total animal }\end{array}$ & $\begin{array}{l}\mathbf{N} \\
\mathbf{L}\end{array}$ & $\begin{array}{l}111.500 \\
112.6\end{array}$ & $\begin{array}{l}0.059 \\
0.073\end{array}$ & $\begin{array}{l}1.25 \\
1.57\end{array}$ & 125 \\
\hline
\end{tabular}

Average retention per normal animal of tagged phosphorus administered 27.6 per cent.

Average retention per leukemic animal of tagged phosphorus administered 35 per cent. 
J. H. LAWRENCE, L. W. TUtTle, K. G. SCOTT, AND C. L. CONNOR

RETENTION OF PIE PER GRAM IN VARIOUS TISSUES

TOTAL ANIMAL

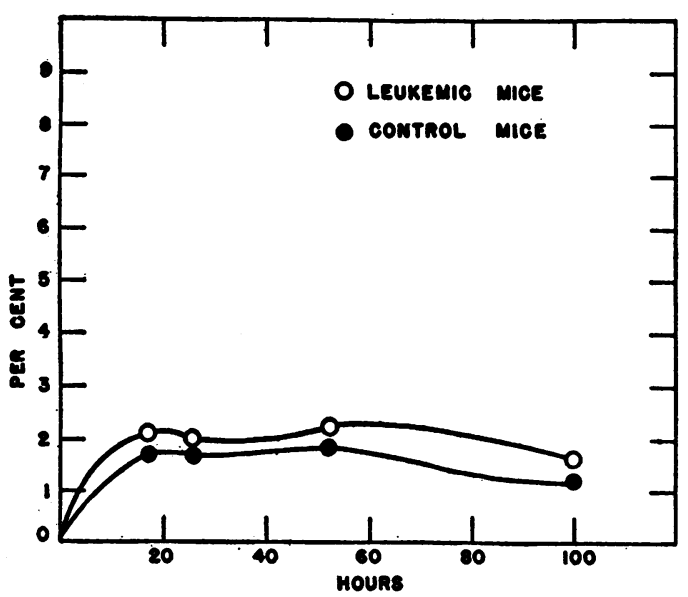

MUSCLE

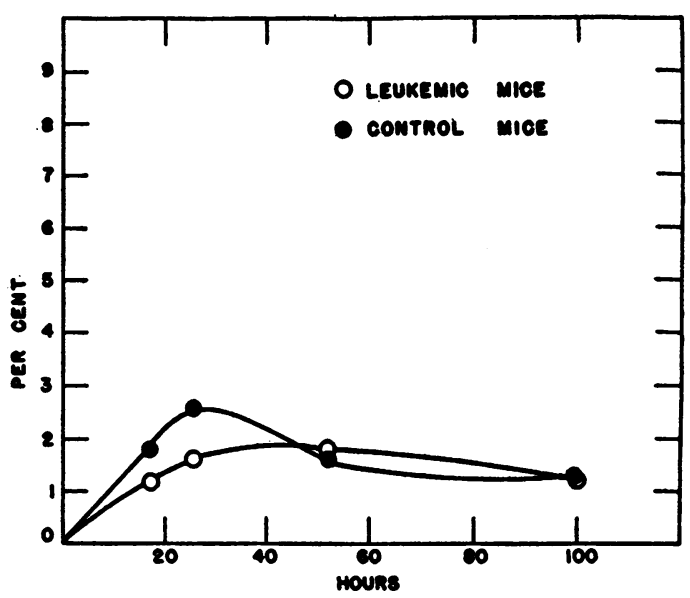

BONE

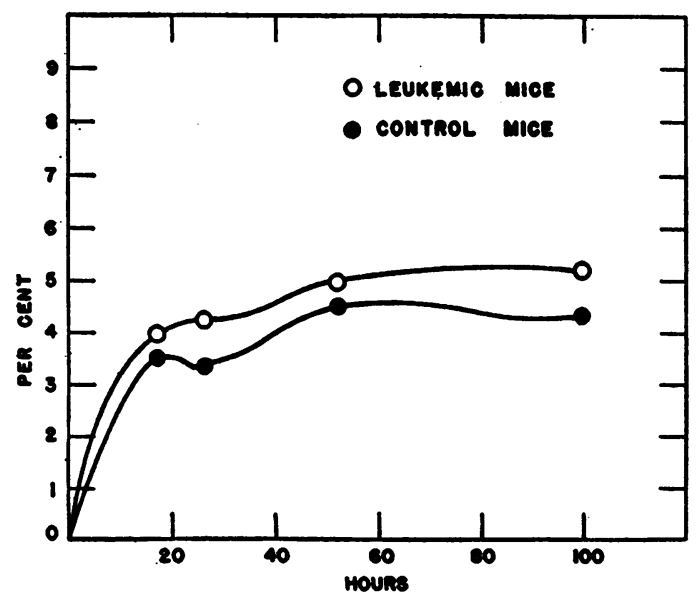

LIVER

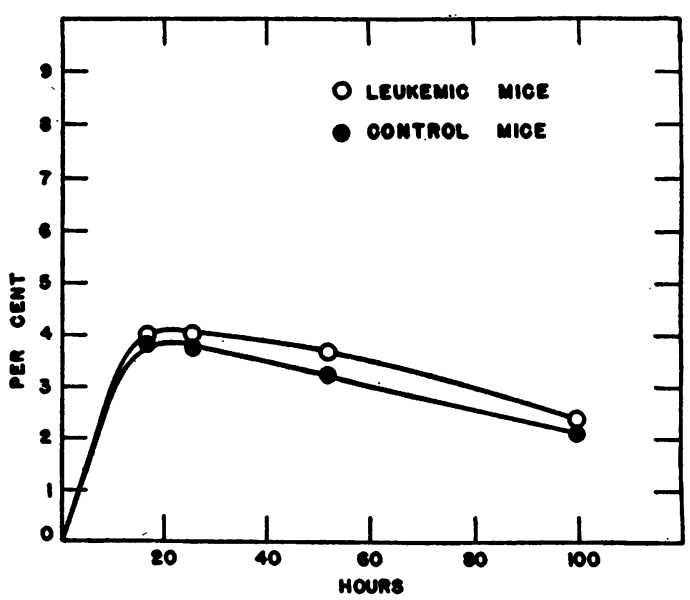

LYMPH NODE

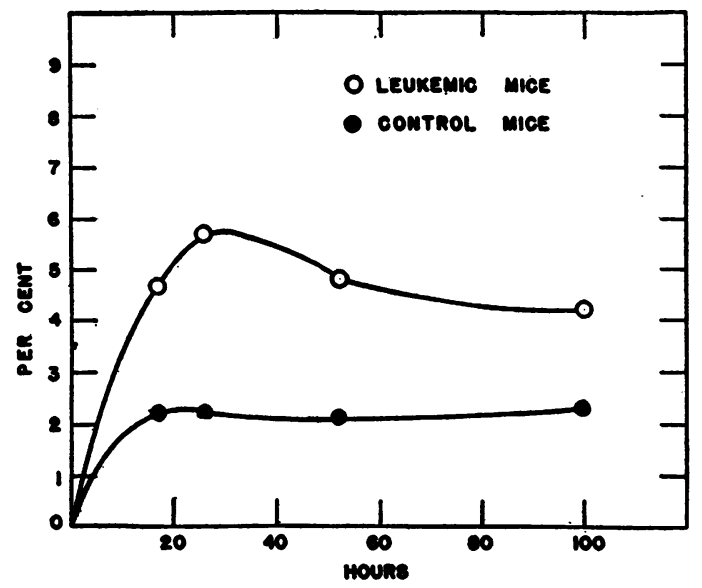

SPLEEN

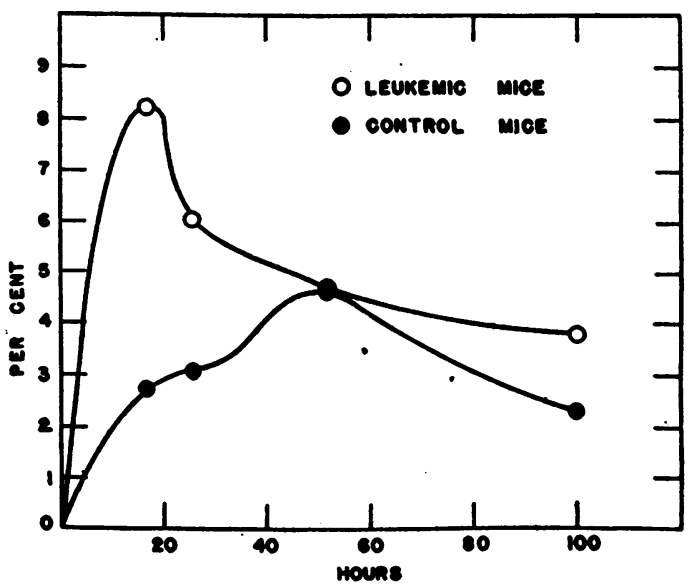

Fig. 1. Relative Exchange of Radionctive Phosphorus in Normal and Leukemic Animals

Each point represents the tissues from 5 animals. The activities per gram wet weight are plotted against hours after injection of $\mathrm{P}^{22}$ in the form of $\mathrm{Na}_{2} \mathrm{HPO}_{4}$ and they are expressed in per cent of dose per gram of tissue. 


\section{DISCUSSION AND SUMMARY}

The uptake of radio-phosphorus in 20 leukemic and 20 normal animals during the 100 hours before sacrificing has been compared. Gross and microscopic examination of the animals showed that the lymph nodes, the spleens, the livers and the bone marrows of the leukemic animals were infiltrated with leukemic cells, whereas the skeletal muscle showed no infiltration. The average uptake per gram of whole body and bone was only slightly greater in the leukemic animals, while the uptake in muscle was slightly less in the leukemic animals. On the other hand, the uptake and exchange in leukemic spleen and lymph gland are strikingly greater than normal. In previous work (1) it was shown that when mice have local lymphomatous tumors the greater uptake and exchange in this tissue occur partially at the expense of whole bone and liver. If the markedly greater uptake of phosphorus in the spleen and lymph nodes of leukemic animals of the present experiment is related to the extensive infiltration of these organs with leukemic cells, then one would expect a similar large uptake in other infiltrated tissues such as liver and bone (which includes bone marrow). As noted in the figures, the observations in these experiments do not show this. A reasonable explanation would seem to lie in the probability that "stealing" of available phosphorus from bone, liver and muscle has occurred as a result of the large deposition of phosphorus in leukemic tissue generally. Also it is probable that the metabolism of phosphorus in bone marrow is largely masked by the metabolism of phosphorus in cortical and cancellous bone, since the latter has such a high content of phosphorus. It seems impossible at the present time to analyze accurately the factors which are concerned in the uptake and exchange of the phosphorus element in these normal and leukemic tissues. We have shown that there is little, if any, difference in the total phosphorus content of infiltrated or uninfiltrated lymph node, spleen, or liver. The uptake or exchange of this element must be associated with the metabolism of the many in- organic and organic compounds (nucleo-proteins, phospholipids, etc.) and with the building of new tissue, which contains phosphorus as an essential constituent. In the case of leukemic tissue the greater uptake and exchange would seem to be related to, first, the rapid building of new tissue, and second, the greater rate of metabolism of this tissue. It is clear that the uptake of a single dose of phosphorus by any tissue is independent of the total phosphorus content of that tissue. Fractionation of the various organic and inorganic phosphorus compounds in the tissues is being carried out to throw light upon these questions in normal and diseased conditions. From the practical standpoint, it seems important to note that, in the leukemic animals, the tissues having the highest activities are spleen, bone, lymph node and liver, and these are the tissues predominantly involved in the leukemic process. Unlike x-rays, which penetrate great distances in tissue, the beta-rays from radio-phosphorus penetrate less than a centimeter and thus act locally. Therefore, the relatively high concentration of radio-phosphorus in leukemic tissues gives us a method of somewhat localizing the irradiation to the infiltrated areas, and this should prove valuable in the therapy of this disease.

W.P.A. assistance (Project Number 10695) is acknowledged, and we also wish to thank the staff of the Radiation Laboratory whose generous cooperation made radio-phosphorus available to us.

\section{BIBLIOGRAPHY}

1. Lawrence, J. H., and Scott, K. G., Comparative metabolism of phosphorus in normal and lymphomatous animals. Proc. Soc. Exp. Biol. and Med., 1939, 40, 694.

2. Pregl, F., and Roth, H., Quantitative Organische Mikroanalyse. J. Springer, Berlin, 1935.

3. Strong, L. C., The establishment of the A strain of inbred mice. J. of Heredity, 1936, 27, 21.

4. Lawrence, J. H., and Gardner, W. U., A transmissible leukemia in the A strain of mice. Am. J. Cancer, 1938, 33, 112.

5. Lawrence, E. O., and Cooksey, D., On the apparatus for the multiple acceleration of light ions to high speeds. Phys. Rev., 1936, 50, 1131. 